\title{
Development of a Hydrological Model for Kala Oya Basin Using SWAT Model
}

\author{
A.D.S. Iresh, A.G.N.S. Marasinghe, A.M.T.S.H. Wedanda, \\ G.P. Wickramasekara, M.D.J.P. Wickramasooriya and M.T.C. Premathilake
}

\begin{abstract}
Streamflow estimation is an important aspect of river basin management and development. Kala Oya stream is about $145 \mathrm{~km}$ in length and is the third-longest river in Sri Lanka [1]. In this study, a Rainfall-Runoff (RR) model has been developed for the Kala Oya basin using the Soil and Water Assessment Tool (SWAT). SWAT is a continuous-time and spatially distributed hydrological model [2] available in the public domain. It is a water-based model developed by the United States Department of Agriculture Research Service [3]. SWAT model output was calibrated using the SWAT-CUP numerical computer program. Daily streamflow data of two river gauging stations at Kala Oya and Dambulla were used to calibrate the RR model with eight parameters. The RR model calibrated using Nash Sutcliffe Efficiency (NSE) statistical index. The calibrated NSE for Kala Oya was 0.59. The calibrated parameters were validated with NSE 0.56. The simulated daily flow was compared with the past published results.
\end{abstract}

Keywords: Kala Oya, SWAT model, Rainfall-Runoff, Swat Cup

\section{Introduction}

Selection of a rainfall-runoff model is a compromise between model complexity and available input data [4]. Complex hydrological models represent the hydrological process better than simple less data-intensive or empirical relations based models. Assumptions made in complex models lead to more reliable results. Simple less data-intensive or empirical relations based models may provide good or better simulations than physically-based hydrological models. Major limitations of simple or empirical models are that they will not represent the complex hydrological system. These models may consider only one or fewer data out of all hydrological data types. Among the available hydrological models, the Soil and Water Assessment Tool (SWAT), is a physically-based distributed hydrological model, and has proved its efficiency to assess different hydrological problems for a broad range of scales and environmental conditions across the globe [5]. A comprehensive review of SWAT model applications, calibration, validation, and uncertainty analysis are given by many researchers [2], [3], [4], [5], [6], [10].

Even though the number of SWAT applications in Sri Lanka is limited compared to SWAT applications in different regions of the world, there are some significant and various applications, from basic water balance method to complex natural environmental assessment. The application of SWAT model to Kala Oya basin reveals that, despite a few limitations, it has a promising degree of reliability to clarify the basin hydrology with regard to sustainability of water resources management.

Eng. A.D.S. Iresh, C. Eng., MIE(SL), IESL Part I, II, III, M.Tech. (India), Dip.Irrig.Eng (ITIG), Irrigation Engineer (Hydrology Division), Irrigation Department, Sri Lanka. Email:shahikairesh@gmail.com

ORCID ID: https://orcid.org/0000-0003-2345-3769

Eng. A.G.N.S. Marasingha, AMIE(SL), B.Sc. Eng (Hons) (Moratuwa Earth Resource Engineer (Puttalam Range), Irrigation Department, Sri Lanka.

Email:salasameera@gmail.com

Eng. A.M.T.S.H. Wedanda, AMIE(SL), B.Sc. Eng (Hons) (Peradeniya), Irrigation Engineer (Anuradhapura Range), Irrigation Department, Sri Lanka.

Email:tiroshi.hashani@gmail.com

Mrs. G.P. Wickramasekara, Dip.Irrig.Eng (ITIG),

Diploma (GIS \& RS), Engineering Assistant (GIS Branch), Irrigation Department, Sri Lanka.

Email:gisbranchgayani@gmail.com

Eng. M.D.J.P. Wickramasooriya, AMIE(SL), B.Sc. Eng (Hons) (Moratuwa), Irrigation Engineer (Colombo Range), Irrigation Department, Sri Lanka.

Email:janaka.irrigation@gmail.com

Eng. M.T.C. Premathilaka, AMIE(SL), B.Sc. Eng (Hons) (Ruhuna), Irrigation Engineer (Assets Management), Irrigation Department, Sri Lanka.

Email:tharindu01107@gmail.com 


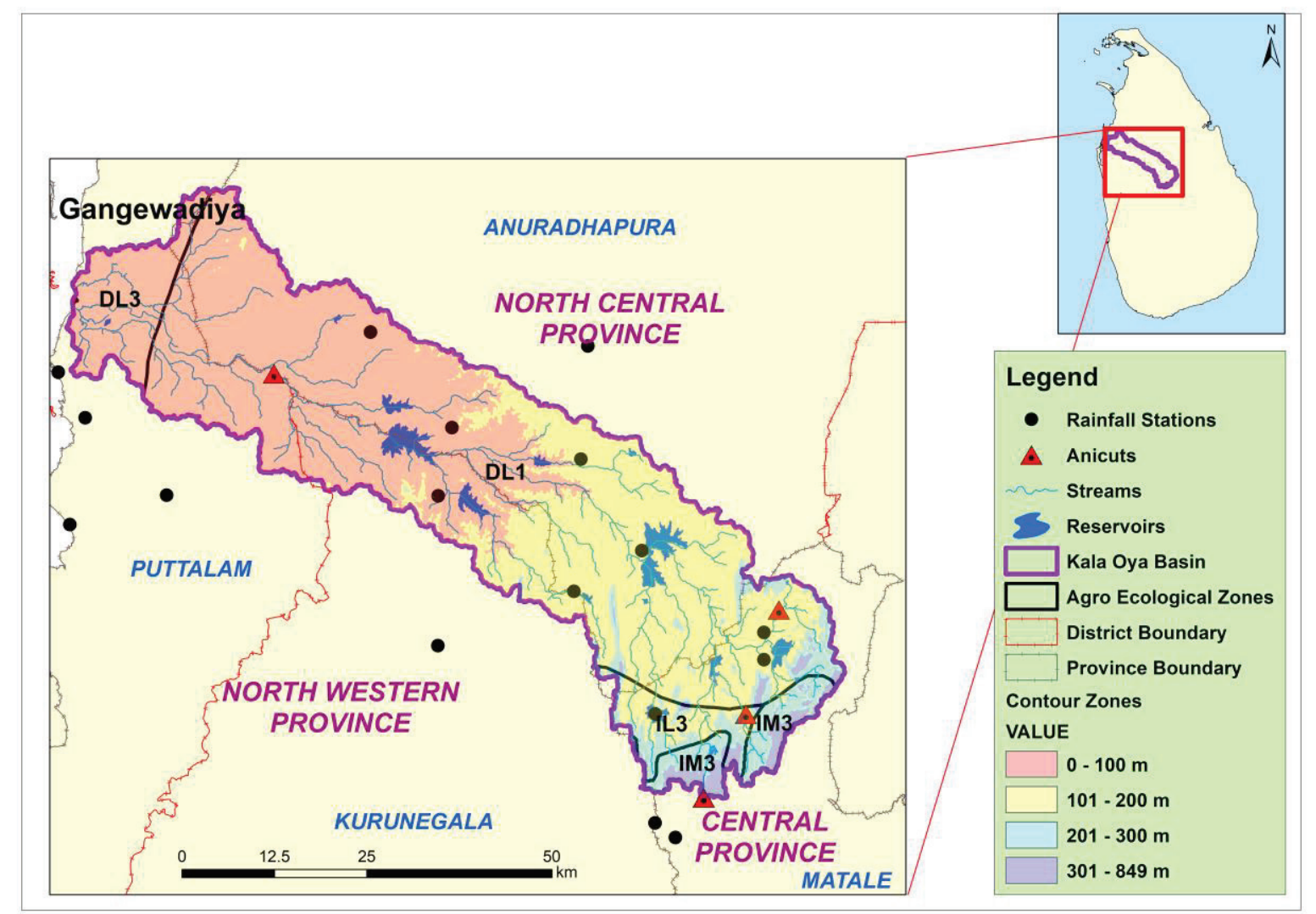

Figure 1 - Kala Oya Basin

\section{Study Area}

Kala Oya basin area covers about 2,870 square kilometres. The area mainly falls within two agro-ecological regions, i.e. DL1 and DL3, as shown above in Figure 1. Kala Oya originates at an elevation around 870 metres Above Mean Sea Level (AMSL) [1]. The upper part of the basin falls within the Matale district and the middle reach falls within the Anuradhapura and Kurunegala districts while the lower reach is located in the Puttalam district. Anuradhapura and Puttalam districts, being in the dry zone, the basin faces huge water scarcity most of the time during the year. The majority (about 52\%) of the catchment area is located in the North Central Province while about $30 \%$ of the catchment area is in the North-Western Province. Kala Oya is one of the longest rivers that flows through many districts and most of its water sources are used to meet the agriculture requirements in the basin. About $90 \%$ of the water utilisation is for paddy cultivation. About $97 \%$ of the basin lies in the flat terrain of the dry zone and balance 3\% lies in the intermediate zone which comprises steep mountains.

\section{Methodology}

The main aim of this study is to develop a Rainfall-Runoff (RR) model to the Kala Oya basin using the SWAT model. SWAT model with Arc GIS interface, (ArcSWAT) is a physically-based semi-distributed model. ArcSWAT model has been used for rainfallrunoff modelling of the basin. SWAT-CUP computer programme has been used for the model calibration, validation and sensitivity analysis. Figure 2 shows the schematic diagram of the study. Initially, the basin was studied to identify its water resources and the required data for SWAT model setup. The data have been collected from different organizations such as Meteorology Department, Irrigation Department, Land Use and Policy Planning Department etc. The meteorological data time series trend analysis, gap-filling and consistency checks have been carried out with respect to the collected data during data screening. Subsequently, processed hydrometeorological data was used for the model simulation after model sensitivity analysis. The observed streamflow gauge data available from 1989 to 1995 have been used for the model calibration and validation. 


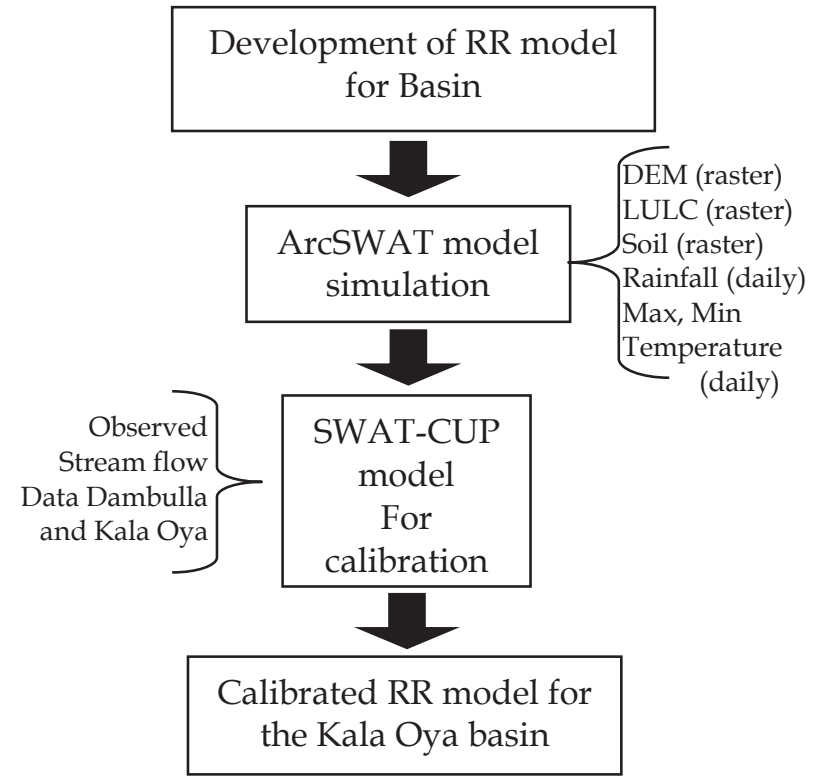

Figure 2 - Aim of the Study

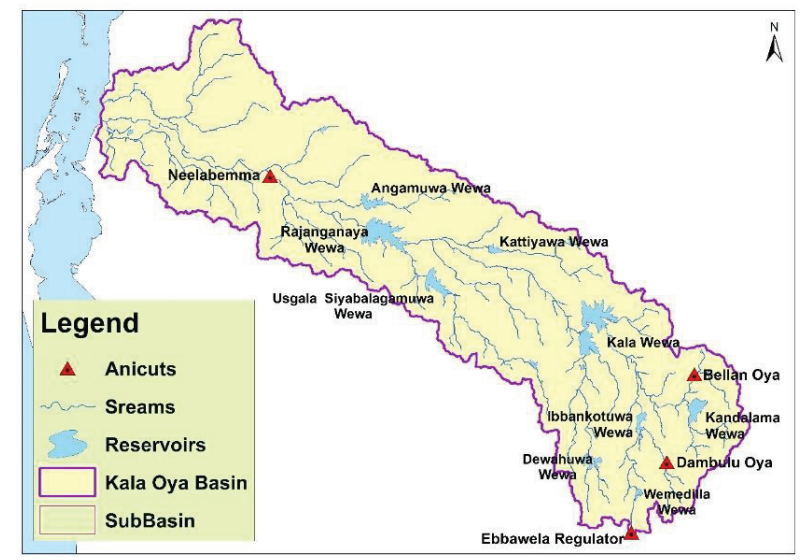

Figure 3 - Water Resources in the Kala Oya Basin

\section{Hydrology and Topography}

The river originates at Dambulla, Kandalama mountains and flows in the North-Western direction. In the lower reaches, few tributaries join the main river and fall to the sea at a place called Gangewadiya [1]. The average annual rainfall of the basin is about $1192 \mathrm{~mm}$. Low flows in the river can be seen in June, July and August. The minimum and maximum temperature in the basin varies from $14.9^{\circ} \mathrm{C}$ to $38.5^{\circ} \mathrm{C}$. The topography of the catchment is flat in the lower part of the basin which consists of mostly forests. The basin is rectangular in shape but when the stream reaches the sea, it gets a funnel shape. Majority of the basin is on the lowest peneplain ( $0 \mathrm{~m}$ to $300 \mathrm{~m}$ AMSL) and the upper part of the basin lies on the middle peneplain (300 m to $1500 \mathrm{~m}$ AMSL). Presently, there are many small tanks and nine major reservoirs constructed damming the Kala Oya and its tributaries. Besides, there are seven medium reservoirs and three anicut structures in the basin as shown in Figure 3.

\section{SWAT Model}

ArcSWAT is an ArcGIS, ArcView extension and interface for SWAT. SWAT is a continuous-time model which can operate on a daily time step at the basin scale. 30 metre resolution Digital Elevation Model (DEM), Land Use and Land Cover (LULC), Soil Data and, daily hydrological data such as rainfall, maximumminimum temperature, and observed river flow have been used for the SWAT model setup.

Table 1 - Details of Required Data for ArcSWAT Model

Data Type Scale Source Data Description/Properties

\begin{tabular}{|c|c|c|c|}
\hline Topography & $30 \mathrm{~m}$ & $\begin{array}{l}\text { Shutter Radar Topographic } \\
\text { Mission (SRTM) } \\
\text { http:/ / srtm.csi.cgiar.org/ }\end{array}$ & Digital Elevation Model (DEM) \\
\hline $\begin{array}{l}\text { Land Use } \\
\text { Land Cover }\end{array}$ & $24 \mathrm{~m}$ & $\begin{array}{c}\text { Land Use and Policy Planning } \\
\text { Department, Sri Lanka }\end{array}$ & $\begin{array}{l}\text { Raster data classified into } \\
\text { different land use classes }\end{array}$ \\
\hline Soil & $10 \mathrm{~m}$ & $\begin{array}{c}\text { International Water } \\
\text { Management Institute (IWMI) }\end{array}$ & $\begin{array}{l}\text { Different Soil Classes, Soil } \\
\text { properties (raster data) }\end{array}$ \\
\hline Meteorological & Daily Data & $\begin{array}{c}\text { Metrological Department, Sri } \\
\text { Lanka }\end{array}$ & $\begin{array}{l}\text { Daily Rainfall, Daily Max. and } \\
\text { Min. Temperature }\end{array}$ \\
\hline Hydrological & Daily Data & $\begin{array}{c}\text { Irrigation Department, Sri } \\
\text { Lanka }\end{array}$ & Daily Discharge \\
\hline
\end{tabular}




\subsection{Data Collection and Processing}

Required key data for the SWAT model, along with the data collected from different sources, are presented in Table 1. Data-screening prior to modelling and designing of water development schemes is an essential requirement [1]. Initially, raw data was screened before using the data for SWAT model using the method adopted by Iresh [1]. Daily time series data of seventeen rainfall stations and four temperature stations, from 1989 to 1995, have been used to evaluate the homogeneity and heterogeneity of the data.

\subsection{Sub Basin Selection and Delineation}

Entire Kala Oya basin is divided into 35 subbasins according to the major and medium reservoirs and anicuts to carry out the studies as shown in Figure 4. Watershed delineation based on DEM is the prerequisite to set up SWAT model. Entire basin is delineated using the DEM with 35 sub-basins in ArcSWAT, in developing the basin model.

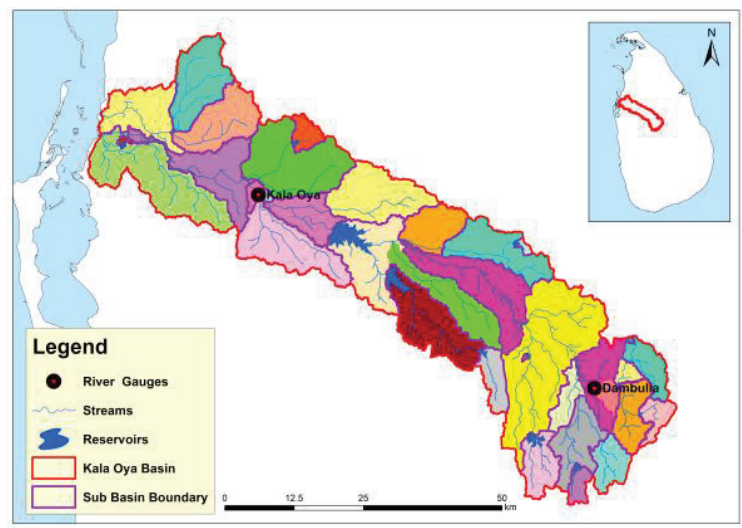

Figure 4 - Sub Basin and River Gauging Station Location Map

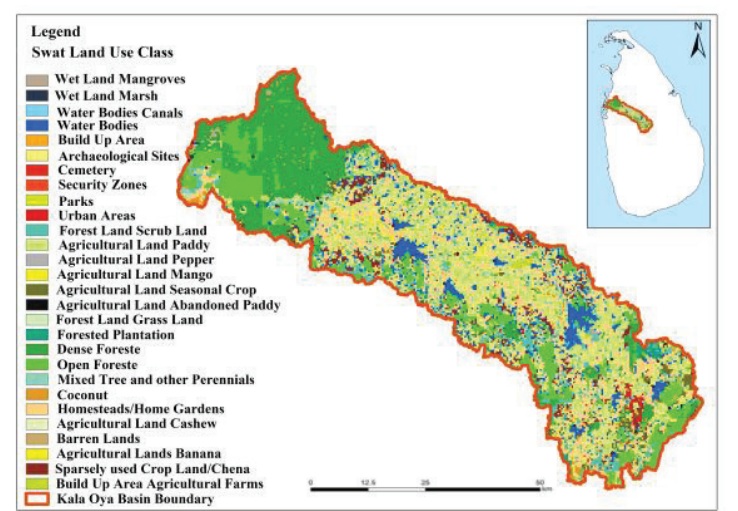

Figure 5 - Land Used and Land Classification Map

\subsection{Precipitation Data}

Daily precipitation data are available at seventeen stations as listed in Table 2. Missing data and gaps in long term precipitation data were filled using data of nearby stations. The method adopted for gap filling was the inversedistance method. If there was no rainfall data at the nearby stations for that particular period, the long-term average daily precipitation of that particular station was used to fill the gaps.

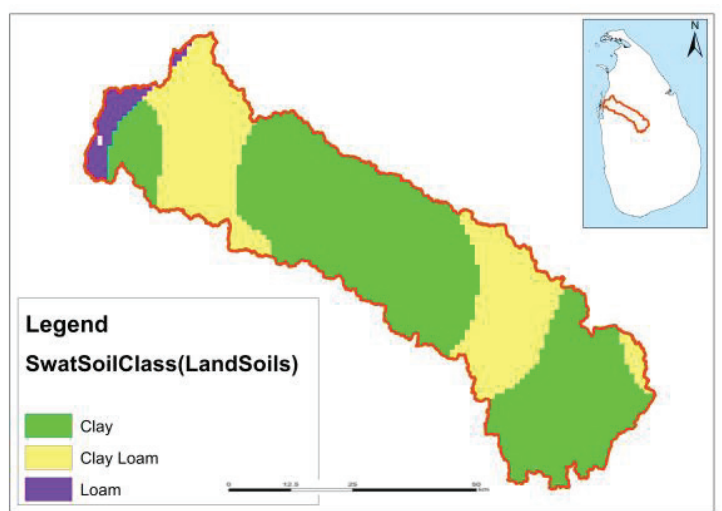

Figure 6 - Kala Oya Basin Soil Map

Table 2 - Details of Rainfall Stations

\begin{tabular}{llrr}
\hline Stn. & \multirow{2}{*}{ Station Name } & \multicolumn{2}{c}{ Co-ordinate } \\
No & & Easting & Northing \\
\hline St.01 & Mahailuppallama & 80.459 & 8.112 \\
St.02 & Kalawewa Tank & 80.534 & 8.000 \\
St.03 & Mahagalkadawala & 80.284 & 8.067 \\
St.04 & Siyabalangamuwa & 80.451 & 7.950 \\
St.05 & Pelwehera & 80.684 & 7.900 \\
St.06 & Dewahuwa & 80.551 & 7.800 \\
St.07 & Kandalama & 80.684 & 7.867 \\
St.08 & Nochchiyagama & 80.201 & 8.267 \\
St.09 & Karaitivu & 79.818 & 8.217 \\
St.10 & Karandipooval & 79.851 & 8.161 \\
St.11 & Nachchaduwa & 80.468 & 8.250 \\
St.12 & Tabbowa & 79.951 & 8.067 \\
St.13 & Millawana- & & \\
St.14 & Mulcade & 80.576 & 7.649 \\
St.15 & Mediyawa Tank & 80.551 & 7.667 \\
St.16 & Puttalam & 79.834 & 7.883 \\
St.17 & Tabuttegama & 80.301 & 8.031 \\
\hline
\end{tabular}

\subsection{Observed Stream Flow Data}

Observed daily Streamflow data at Dambulla and Kala Oya stations, which are located at the sub-basin outlets of 29 and 10 from 1989 to 1995, was obtained from the Irrigation Department Hydrology Division, Sri Lanka as given in Table 3. 


\subsection{SWAT Model Setup Development}

ArcSWAT Model setup is developed using DEM, land use data, soil data, and slope classes. The land use map, soil map, and basin slope map are presented in Figures 5, 6, and 7, respectively. Two slope classes are assigned to the model set up by DEM histogram analysis. 28 LULC classes were identified during the LULC classification. Three major soil classes were identified inside the Kala Oya basin during soil raster data classification. Classified soil types belong to clay, clay loam and loam. Using observed rainfall and temperature (Tmax and Tmin) time-series data, 35 numbers of synthetic rainfall and temperature time-series data have been generated for each sub-basin centres, using the well-known inverse distance method. Original daily rainfall/temperature time-series data and synthetically generated rainfall/temperature time-series data (to the basin centres) have been used for model simulation. Then checked the NSE (Nash
Sutcliffe Efficiency) with observed data for the calibration period in ArcSWAT model. It has been found that synthetically generated data for each sub-basin centre gives better NSE than original data.

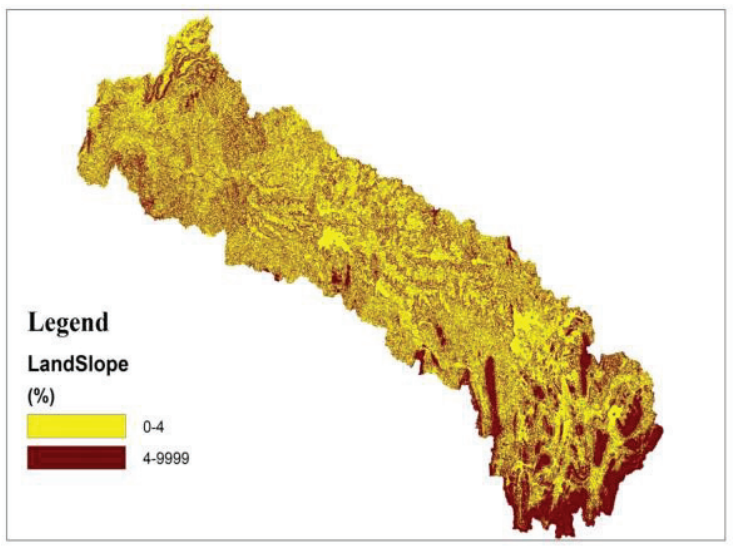

Figure 7 - Slope Class Map

Table 3 - River Gauging Station Details

\begin{tabular}{lllcl}
\hline $\begin{array}{l}\text { Gauge } \\
\text { Name }\end{array}$ & \multicolumn{2}{c}{ Co-ordinate } & Calibration Period & \multirow{2}{*}{ Validation Period } \\
\hline Kala Oya & 80.097 & 8.198 & $1989 / 10 / 01-1992 / 09 / 30$ & $1992 / 10 / 01-1995 / 08 / 31$ \\
Dambulla & 80.647 & 7.884 & $1989 / 10 / 01-1992 / 09 / 30$ & $1992 / 10 / 01-1995 / 08 / 31$ \\
\hline
\end{tabular}

Table 4 - Calibrated Model Parameters

\begin{tabular}{llccc}
\hline SWAT Parameter & Description & $\begin{array}{c}\text { Fitted } \\
\text { Value }\end{array}$ & $\begin{array}{c}\text { Min. } \\
\text { Value }\end{array}$ & Max. Value \\
\hline CH_K2.rte & $\begin{array}{l}\text { Effective hydraulic conductivity in } \\
\text { main channel alluvial (mm/h) }\end{array}$ & 180.0187 & 180.0032 & 180.047 \\
ESCO.bsn & Soil evaporation compensation factor & 0.0999 & 0 & 0.1 \\
CANMX.hru & Maximum canopy storage (mm water) & 34.356 & 34.356 & 34.3563 \\
SLSUBBSN.hru & Average slope length (m) & 161.158 & 161.1576 & 161.1583 \\
CN2.mgt & SCS runoff curve number & 67.9064 & 67.9064 & 67.9064 \\
ALPHA_BF.gw & Baseflow alpha-factor (days) & 0.9998 & 0.9857 & 1 \\
GW_DELAY.gw & Groundwater delay (days) & 146.4658 & 146.4657 & 146.4658 \\
& $\begin{array}{l}\text { Threshold depth of water in the } \\
\text { shallow aquifer required for return }\end{array}$ & 213.9087 & 213.9008 & 213.9361 \\
GWQMN.gw & flow to occur (mm) & & & \\
\hline & & & &
\end{tabular}


Table 5 - Calibrated Model Statistical Parameters Detail

\begin{tabular}{|c|c|c|c|c|}
\hline Variable & $\begin{array}{l}\text { Coefficient of } \\
\text { Determinant } \\
\qquad\left(R^{2}\right)\end{array}$ & $\begin{array}{c}\text { Nash } \\
\text { Sutcliff } \\
\text { Efficiency } \\
\text { (NSE) }\end{array}$ & $\begin{array}{c}\text { Percentage } \\
\text { Bias (PBIAS) }\end{array}$ & $\begin{array}{c}\text { Ratio of Root Mean } \\
\text { Square Error to } \\
\text { Standard Deviation } \\
\text { (RSR) }\end{array}$ \\
\hline FLOW_OUT_10 (Kala Oya) & 0.59 & 0.59 & 8.2 & 0.64 \\
\hline FLOW_OUT_29 (Dambulla) & 0.39 & 0.36 & 21.5 & 0.8 \\
\hline
\end{tabular}

Table 6 - Validated Model Statistical Parameters Detail

\begin{tabular}{ccccc}
\hline Variable & $\begin{array}{c}\text { Coefficient of } \\
\text { Determinant } \\
\left(\mathrm{R}^{2}\right)\end{array}$ & $\begin{array}{c}\text { Nash Sutcliff } \\
\text { Efficiency } \\
(\mathrm{NSE})\end{array}$ & $\begin{array}{c}\text { Percentage } \\
\text { Bias } \\
\text { (PBIAS) }\end{array}$ & $\begin{array}{c}\text { Ratio of Root mean } \\
\text { square error to } \\
\text { Standard deviation } \\
\text { (RSR) }\end{array}$ \\
\hline FLOW_OUT_10 (Kala Oya) & 0.56 & 0.5 & -9.2 & 0.7 \\
FLOW_OUT_29 (Dambulla) & 0.27 & 0.27 & 12.1 & 0.86 \\
\hline
\end{tabular}
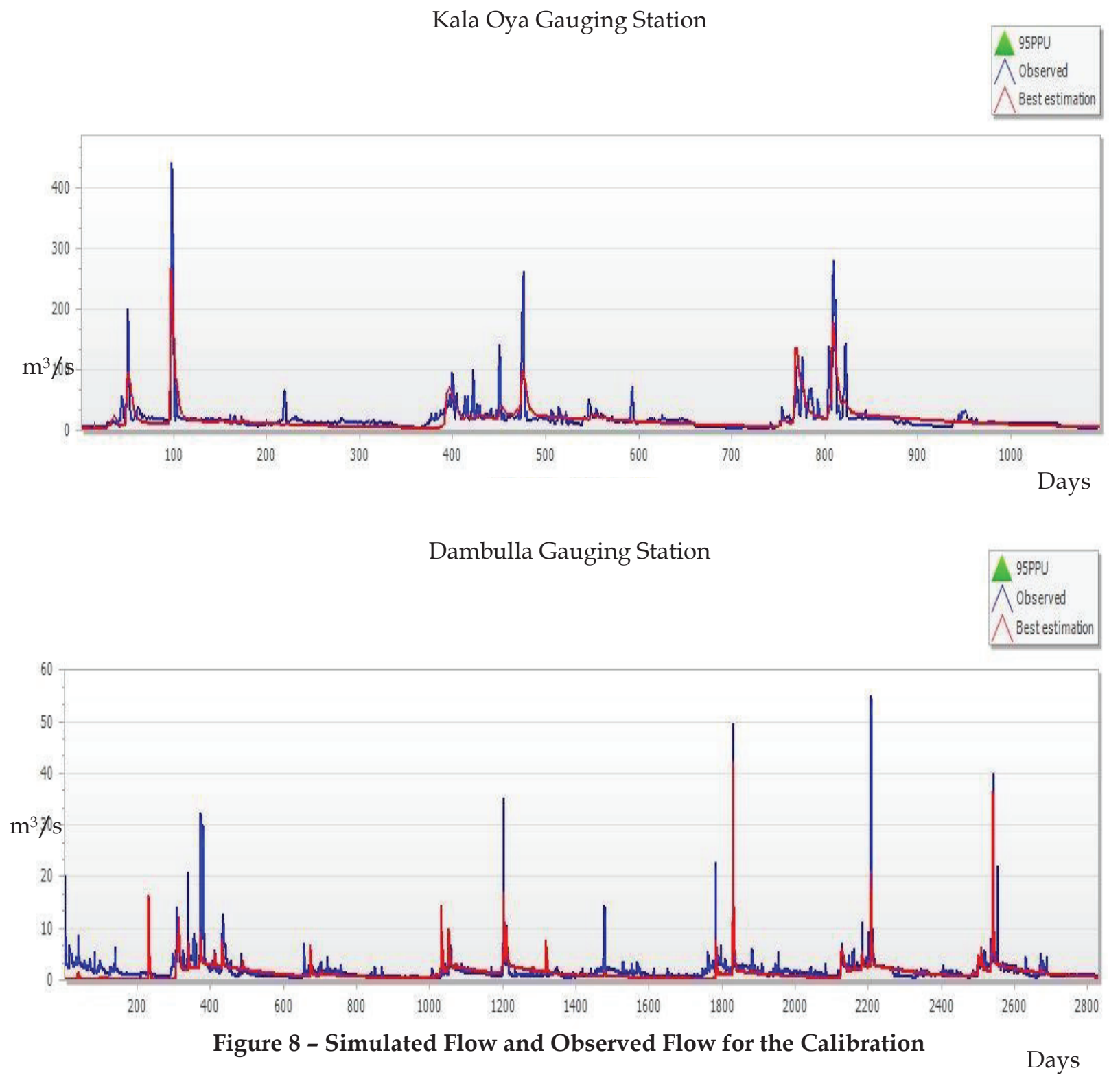

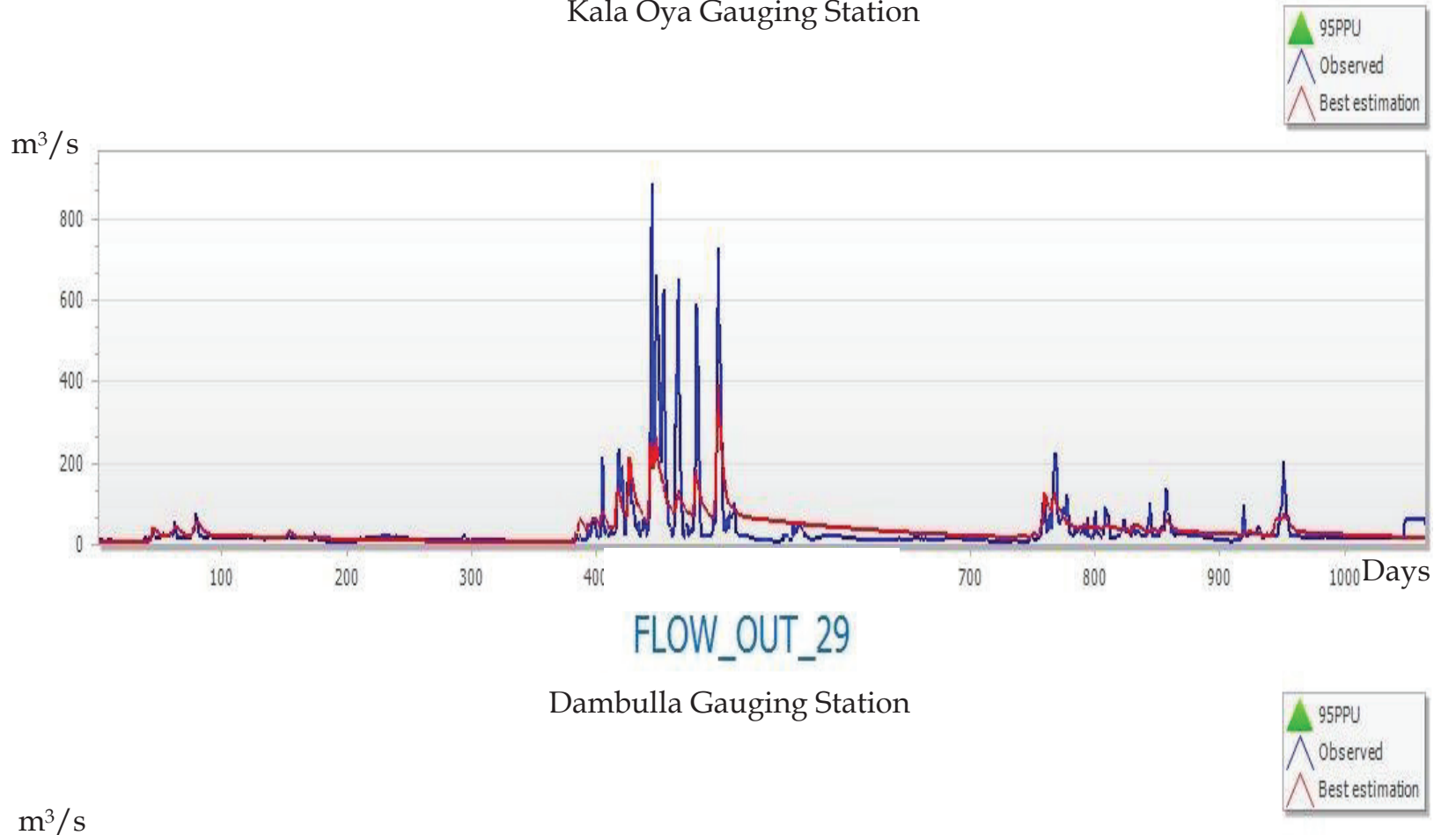

$\mathrm{m}^{3} / \mathrm{s}$

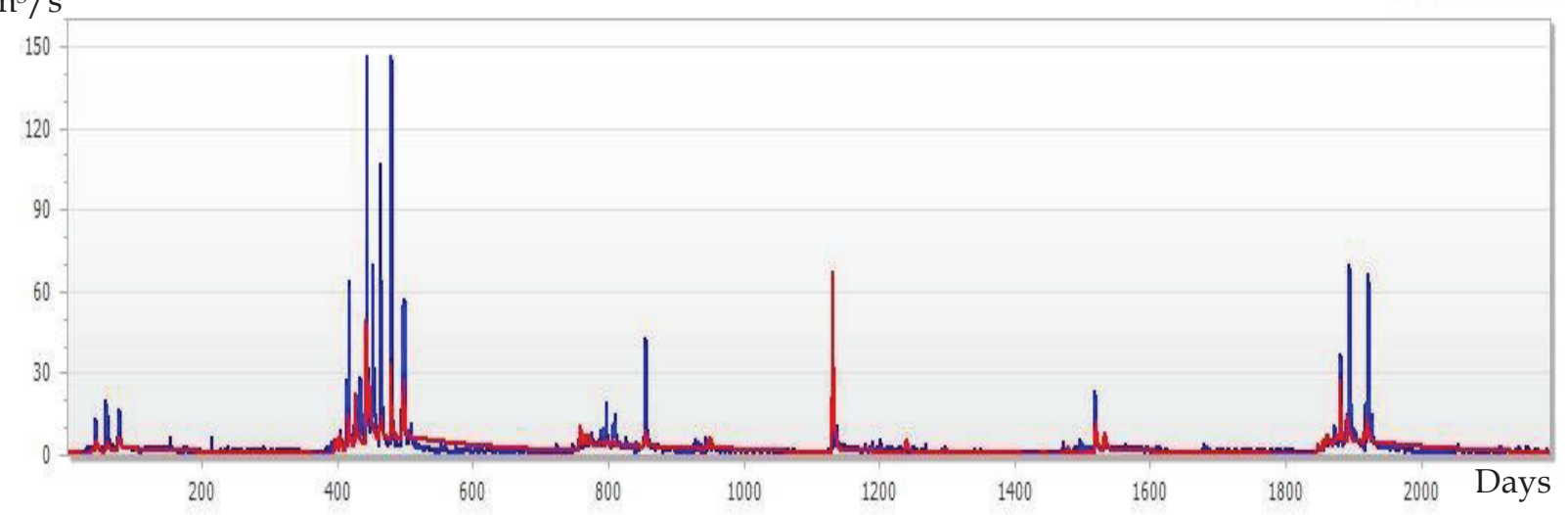

Figure 9 - Simulated Flow and Observed Flow for the Validation

This is because the ArcSWAT model has been developed by the developer to use closest subbasin station (rainfall, temperature, etc.) data for the model simulation. Synthetic data have been generated for each sub-basin centre using available station data. This synthetic data is uploaded to the model for RR simulation. The model produced better results than original station time-series data. All the data have been uploaded to the model with the coordinates of station locations. After loading all input data and generating the required database files, ArcSWAT model has been initially simulated, using model default parameter values. ArcSWAT model output has been used to calibrate the model parameters using SWATCUP computer programme.

\subsection{Model Calibration}

SWAT-CUP is a public domain available computer program for calibration, validation and uncertainty analysis of SWAT model output. The program is linked with Sequential Uncertainty Fitting version 2 (SUFI-2), Particle Swarm Optimization (PSO), Generalized Likelihood Uncertainty Estimation (GLUE), Parameter Solution (Para Sol), and Markov Chain Monte Carlo (MCMC) algorithm procedures to calibrate the SWAT model output. In this study, SUFI-2 algorithm was used for the model calibration and validation. SUFI-2 algorithm is a semi-automated inverse modelling procedure for a combined calibration uncertainty analysis [6]. SUFI-2 algorithm can optimize the parameters within the range based on the given objective function (e.g., based on NSE, Root Mean Square Error, etc.). Available discharge data, October 1989 to August 1995, 
was distributed into two parts; the period from October 1985 to September 1992 was used for calibration purpose whereas October 1992 to August 1995 data was used for validation of the calibrated model as shown in Table 3. Using the ArcSWAT output, SWAT-CUP model setup was developed and simulated including 21 numbers of parameters. Hence the most sensitive parameters were analysed. Most sensitive 8 numbers of parameters have been selected for the model calibration. The model was calibrated using the observed streamflow data at Kala Oya and Dambulla stream gauging stations. Table 4 and Table 5 show the calibrated parameters and statistical parameters of the observed and simulated data. Figure 8 gives the graph with the simulated flow and observed flow for the calibrated period.

\subsection{Model Validation}

Using the calibrated parameters, SWAT-CUP model was validated for the validation period. Table 6 shows the statistical parameters of the model for the validated period. Figure 9 gives the graph with the simulated flow and observed flow for the validated period.

\section{Comparison of the Results with Past Studies}

Table 7 shows important studies/literature among the various case studies on the Kala Oya basin. SWAT model simulated annual average flow has been compared with the past literature. According to Arumugam [7], annual average flow to the sea is very much closer to calibrated annual outflow. National Atlas [8] annual outflow has a significant difference to other methods. These results show that there is considerable similarity compared to annual average outflow stated by Arumugam [7].

\section{Conclusions}

During model calibration, NSE output was 0.59 and 0.39 for Kala Oya and Dambulla gauging sites, respectively. During model validation, NSE results were 0.50 and 0.27 for Kala Oya and Dambulla gauging sites, respectively. Percentage bias (PBIAS) also gave 8.2, 21.5 and -9.1, 12.1 for calibration and validation, respectively. This confirmed that PBIAS lies within \pm 25 and it can be concluded that the calibrated model gives a good performance rating for daily streamflow model simulation [9]. In general, model simulation can be judged as satisfactory if NSE $>0.50$ and RSR $\leq 0.70$, and if PBIAS $\pm 25 \%$ for streamflow [9].
Accounting for the high flows during model simulation has not given greater accuracy. But, accounting the low flows has a good accuracy than high flows. In general, the model setup developed by this study has been calibrated and validated with satisfactory accuracy at Kala Oya gauging site. The model accuracy could have been increased further if much longer observed flow data were available. Calibrated model parameters can be used for the real-time flood forecasting, flood monitoring and in water issue planning during crop cultivation. The main disadvantage of this study was that there are no existing stream gauging stations along the river after the year 1995. Kala Oya and Dambulla gauging stations were abandoned in 1995 due to construction of new reservoirs. Earlier, there were some gauging stations, and due to construction of new reservoirs, they have been removed and not reestablished. It is time to propose and establish new stream gauging stations along the stream which can be very much useful in future studies and planning.

Table 7 - Comparison of Simulated Flow with Literature

\begin{tabular}{cc}
\hline Reference & $\begin{array}{c}\text { Outflow } \\
\text { (MCM/year) }\end{array}$ \\
\hline $\begin{array}{c}\text { ArcSWAT model } \\
\text { (without SWAT-CUP } \\
\text { calibration) } \\
\text { Calibrated outflow }\end{array}$ & 1128 \\
$\begin{array}{c}\text { Water Resources of } \\
\text { Ceylon, S. Arumugam }\end{array}$ & 1028 \\
National Atlas & 386 \\
\hline
\end{tabular}

\section{Acknowledgement}

Authors wish to acknowledge the assistance and support given by the Irrigation Department officials during the study by providing necessary data and guidance.

\section{References}

1. Iresh, A, D, S., "Screening of Annual Rainfall Time-Series Data in Kala Oya Basin: Case Study in Sri Lanka", Journal of the Institution of Engineers, Sri Lanka., Vol. 53, No 2, 2020, pp. 59-65.

2. Tan, M, L., Ficklin, D, L., Ibrahim, A, L., and, Yusop, Z., "Impact and Uncertainties of Climate Change on Streamflow of the Johor River Basin, Malaysia using a CMIP5 General Circulation 
Models Ensemble", Journal of Water and Climate Change., Vol. 10, No 2166, 2014, pp. 1-20.

3. Sood, A., Muthuwatta, L., and, McCartney, M., "A SWAT Evaluation of the Effect of Climate Change on the Hydrology of the Volta River Basin", Water International., May, 2019.

4. King, K. W., Arnold, J. G., and, Bingner, R. L., "Comparison of Green-Ampt and Curve Number Methods on Goodwin Creek Watershed using SWAT", American Society of Agricultural Engineers., Vol. 42, No 4, 1999, pp. 919-925.

5. Saha, P. P. and, Zeleke, K., "Rainfall-Runoff Modelling for Sustainable Water Resources Management: SWAT Model Review in Australia", Sustainability of Integrated Water Resources Management., Vol. 29, 2017, pp. 563-578.

6. Abbaspour. K. C., Yang, J., Maximov, I., Siber, R., Bogner, K., Mieleitner, J., Zobrist, J., and Srinivasan, R., “Modelling Hydrology and Water Quality in the Pre-Alpine/Alpine Thur Watershed using SWAT", Journal of Hydrology, Vol. 333, 2007, pp. 413-430.

7. Arumugam. S., "Water Resources of Ceylon Its Utilisation and Development" A Water Resources Board Publication, 1969, 5 p.

8. National Atlas of Sri Lanka- 2nd Edition., Survey Department of Sri Lanka, 2012, 60 p.

9. Moriasi. D. N., Arnold, J. B., Van Liew, M. W., Bingner, R. L., Harmel, R. D. and, Veith, T. L., "Modelling Evaluation Guidelines for Systematic Quantification of Accuracy in Watershed Simulations", American Society of Agricultural and Biological Engineers, Vol. 50(3), 2007, pp. 885-900.

10. Khalid. K., Ali. M. F., Rahman. N. F. A., Mispan. M. R.,Haron. S. H, Othman. Z., and Mohd Fairuz Bachok. M. F., "Sensitivity Analysis in Watershed Model using SUFI-2 Algorithm", Procedia Engineering., Vol. 162, 2016, pp. 441-447. 